\title{
EVALUASI PELAKSANAAN PIS-PK DI PUSKESMAS KABUPATEN LABUAN BATU, PROVINSI SUMATERA UTARA DAN KOTA SEMARANG, PROVINSI JAWA TENGAH
}

\section{Evaluation of PIS-PK in Puskesmas Labuan Batu Dsitrict North Sumatera Province and Semarang City, Central Java Province}

\author{
Novianti ${ }^{1}$, Ning Sulistiyowati ${ }^{1}$, Oster Suriani Simarmata ${ }^{1}$, Rachmalina S Prasodjo $^{1}$, Athena \\ Anwar $^{1}$, Eva Laelasari ${ }^{1}$, Joko Irianto ${ }^{1}$ \\ ${ }^{1}$ Puslitbang UpayaKesehatan Masyarakat, Badan Litbangkes \\ Email: novianti.ms@gmail.com
}

Diterima: 8 Januari 2020; Direvisi: 7 Februari 2020; Disetujui: 25 Juni 2020

\begin{abstract}
The Healthy Indonesia Program with Family Approach (PIS-PK) is an effort to strengthen basic health that began in 2015. To get more comprehensive data and information on the implementation of PIS-PK, in 2017 the Center for Public Health Efforts to carry out a PIS-PK evaluation study in several districts/cities in Indonesia. This study uses a quantitative and qualitative approach, in one puskesmas in Labuan Bajo Regency, North Sumatra Province and Semarang City, Central Java Province. Data collection was carried out by means of in-depth interviews about the implementation of PIS-PK including input indicators (personnel, funds, tools and methods), processes (planning, implementation, supervision), and output. The results of the study show that the implementation of input indicators, such as the limited number of Puskesmas human resources in data collection and data entry, also not yet clear about the sources of funding for implementing PIS-PK. On output (results of family visits), there are differences in the results of the calculation of indicators between the results of data collection conducted by PIS-PK puskesmas officers and study results. When compared between the two puskesmas, Puskesmas H Semarang is more ready for PIS-PK than Puskesmas P in Labuan Batu Regency. It can be concluded that in the implementation of PISPK in both puskesmas still encountered problems, both in terms of inputs (personnel, funds, tools and methods), processes (planning, implementation, supervision), and output. As a suggestion, there needs to be more comprehensive planning in implementing PIS-PK.
\end{abstract}

Keywords: PIS-PK, evaluation research, input, process, and output indicator

\begin{abstract}
ABSTRAK
Program Indonesia Sehat dengan Pendekatan Keluarga (PIS-PK) merupakan program upaya penguatan kesehatan dasar yang mulai dilaksanakan pada tahun 2015. Untuk mendapatkan data dan informasi yang lebih komprehensif tentang pelaksanaan PIS-PK, pada tahun 2017 Puslitbang Upaya Kesehatan Masyarakat melakukan studi evaluasi PIS-PK di beberapa kabupaten/kota di Indonesia. Studi ini menggunakan pendekatan kuantitatif dan kualitatif, di salah satu puskesmas di Kabupaten Labuan Bajo, Provinsi Sumatera Utara dan Kota Semarang, Provinsi Jawa Tengah. Pengumpulan data dilakukan dengan cara wawancara mendalam mengenai pelaksanaan PIS PK meliputi indikator input (tenaga, dana, alat dan metode), proses (perencanaan, pelaksanaan, pengawasan), dan output. Hasil studi menunjukkan bahwa pelaksanaan untuk indikator input, seperti masih terbatasnya SDM puskesmas dalam melakukan pendataan maupun entry data, juga belum jelasnya sumber pembiayaan pelaksanaan PIS-PK. Pada output (hasil kunjungan keluarga) terdapat perbedaan hasil perhitungan indikator antara hasil pendataan yang dilakukan oleh petugas PIS-PK puskesmas dengan hasil studi. Jika dibandingkan diantara ke dua puskesmas, Puskesmas H Kota Semarang lebih siap PIS-PK daripada Puskesmas P Kabupaten Labuan Batu. Dapat disimpulkan bahwa dalam pelaksanaan PIS-PK di kedua puskesmas masih menemui permasalahan, baik dalam hal input (tenaga, dana, alat dan metode), proses (perencanaan, pelaksanaan, pengawasan), maupun output. Sebagai saran, perlu adanya perencanaan yang lebih komprehensif dalam implementasi PIS-PK.
\end{abstract}

Kata kunci: PIS PK, riset evaluasi, Indikator input, proses, dan output 


\section{PENDAHULUAN}

Indonesia memiliki masalah kesehatan yang sangat kompleks. Beberapa prevalensi penyakit dan faktor risikonya terus meningkat dari tahun ke tahun. Permasalahan gizi di semua siklus kehidupan belum mencapai target perbaikan yang diharapkan, sebagai contoh adalah masih tingginya kasus balita pendek (stunting) yang hingga kini masih menjadi problematika gizi di Indonesia dan angkanya terus meningkat. Data Riskesdas menunjukkan terjadi peningkatan dari $36,8 \%$ pada tahun 2010 menjadi 37,2 pada tahun 2013 (Badan Litbangkes RI, 2013). Dalam hal upaya pengendalian penyakit kita juga masih dihadapkan pada beban ganda dimana baik prevalensi penyakit menular (AIDS dan TBC) dan penyakit tidak menular (hipertensi, diabetes, kanker dan ganguan jiwa) masih terus meningkat secara statistik di Indonesia (Badan Litbangkes RI, 2013)

Pembangunan kesehatan berkelanjutan diperlukan untuk memutus mata rantai persoalan kesehatan tersebut. Sesuai dengan yang diamanatkan dalam UU Kesehatan Nomor 36 tahun 2009, bahwa pembangunan kesehatan bertujuan untuk meningkatkan derajat kesehatan masyarakat Indonesia. Oleh karena itu, perlu strategi untuk mencapainya. Pada tahun 2015, pemerintah melakukan penguatan dengan mengembangkan upaya kesehatan dasar (primary health care) melalui Program Indonesia Sehat dengan Pendekatan Keluarga PIS-PK). Program ini diharapkan dapat menjadi program utama Pembangunan Kesehatan yang kemudian direncanakan pencapaiannya melalui Rencana Strategis Kementerian Kesehatan Tahun 2015-2019, yang ditetapkan melalui Keputusan Menteri Kesehatan R.I. Nomor HK.02.02/Menkes/52/2015. (Kementerian Kesehatan RI, 2015)

Adapun sasaran dari Program Indonesia Sehat adalah meningkatnya derajat kesehatan dan status gizi masyarakat melalui upaya kesehatan dan pemberdayaan masyarakat yang didukung dengan perlindungan finansial dan pemerataan pelayanan kesehatan. Sasaran ini sesuai dengan sasaran pokok RPJMN 2015-2019, yaitu: meningkatnya status kesehatan dan gizi ibu dan anak, meningkatnya pengendalian penyakit, meningkatnya akses dan mutu pelayanan kesehatan dasar dan rujukan terutama di daerah terpencil, tertinggal dan perbatasan, meningkatnya cakupan pelayanan kesehatan universal melalui Kartu Indonesia Sehat dan kualitas pengelolaan SJSN kesehatan, terpenuhinya kebutuhan tenaga kesehatan, obat dan vaksin, serta meningkatnya responsivitas sistem kesehatan. (Kementerian Kesehatan RI, 2015)

Program Indonesia Sehat yang dilakukan di Indonesia sejak tahun 2015 lalu dilakukan dengan Pendekatan Keluarga. Pendekatan Keluarga dalam program ini diharapkan dapat mampu menyiasati permasalahan akses ke pelayanan kesehatan yang masih sulit dijangkau oleh keluargakeluarga di beberapa tempat. Pendekatan keluarga dalam Program Indonesia Sehat ini merupakan program lanjutan dari adanya program kunjungan Puskesmas yang telah dilaksanakan sebelumnya. (Kementerian Kesehatan RI, 2014).

Berdasarkan hasil penelitian tahun 2016 dibeberapa kabupaten/kota, diketahui bahwa dalam implementasi progam Keluarga Sehat (KS) masih terdapat beberapa permasalahan baik dari aspek tenaga, dana dan prasarana sampai dengan aplikasi komputer dan analisis data. (Laelasari, 2016). Untuk mendapatkan gambaran lebih lengkap terkait pelaksanaan PIS-PK di Indonesia pada tahun 2017 telah dilakukan riset implementasi termasuk melakukan konfirmasi pada rumah tangga. Penelitian tahun 2017 merupakan riset evaluasi PIS-PK terhadap input, proses, dan output implementasi PIS-PK mulai dari tingkat pusat hingga puskesmas sebagai ujung tombak pelaksana, serta uji petik di tingkat rumah tangga/keluarga yang pernah didata oleh puskemas. (Sulistiyowati, 2017) Artikel ini merupakan hasil analisis lanjut yang bertujuan untuk mengetahui kesiapan puskesmas dalam pelaksanaan PIS-PK berdasarkan evaluasi yang dilakukan terhadap input, proses, dan output tersebut.

\section{BAHAN DAN CARA}

Penelitian ini dilakukan di Puskesmas P., Kabupaten Labuan Batu, dan Puskesmas H., Kota Semarang; menggunakan pendekatan kuantitatif dan kualitatif. Lokasi penelitian dilakukan di Kabupaten Labuan Batu, dan 
Kota Semarang. Kedua puskesmas di ke dua kabupaten/kota dipilih karena memiliki minimal empat puskesmas yang telah melakukan pengumpulan data PIS-PK ditingkat rumah tangga secara total sampling. Data kualitatif yang dikumpulkan meliputi informasi tentang indikator input $5 \mathrm{M}$ (sumber daya manusia/SDM, anggaran, metode pengumpulan data, sarana dan prasarana), proses pelaksanaan pendataan PIS PK dan pengolahan data. Data kualitatif diperoleh dengan cara wawancara mendalam, informan adalah tenaga kesehatan di masing-masing puskesmas terpilih yang telah melakukan pendataan PIS-PK minimal empat desa/ kelurahan. Data kuantitatif yang merupakan indikator output berupa validasi terhadap hasil pendataan yang dikumpulkan oleh petugas pengumpul data PIS-PK (kroscek kuesioner rumah tangga dan individu yang telah diisi).

Analisis data kualitatif dilakukan dengan konten tematik, sedangkan data kuantitatif dilakukan secara deskriptif.

\section{HASIL}

Dalam melihat pelaksanaan beberapa indikator yang dilihat dalam mengevaluasi pelaksanaan Program PIS PK di 2 kabupaten tersebut diatas meliputi indikator masukan (input), indikator proses dan indikator keluaran (output), adapun temuan dari ketiga indikator tersebut sebagai berikut:

\section{Indikator Input}

\section{Sumber Daya Manusia}

Semua puskesmas yang menjadi subjek pada penelitian ini menyatakan bahwa tenaga pengumpul data adalah wajib tenaga kesehatan Puskesmas atau minimal D3 bidang kesehatan yang pernah mengikuti pelatihan PIS-PK. Informasi tersebut didapatkan saat pelatihan dilakukan di tingkat provinsi bersama Bapelkes. Namun pada kenyataannya hampir semua petugas Puskesmas baik yang sudah mengikuti pelatihan dan yang belum pernah mengikuti pelatihan dilibatkan dalam pengumpulan data PIS-PK. Tidak sesuainya pelaksana pengumpul data PIS-PK di Puskesmas, disebabkan karena terbatasnya jumlah petugas yang mengikuti pelatihan. Sampai dengan tahun 2016, hanya 4-6 petugas dari masing-masing Puskesmas yang mengikuti pelatihan. Berikut pernyataan yang mendukung:

"Kriteria yang jelas yang pernah dilatih atau minimal terpapar tentang $K S$ ini. Harus tenaga kesehatan latar belakang pendidikannya. Tapi gimana yang dilatih hanya 5 orang, tapi data harus masuk satu bulan untuk satu kelurahan, jadi dikerahkanlah semua yang ada di Puskesmas. (Pendamping Ds. AP, PKM P., Kab. Labuan Batu)

Terbatasnya jumlah petugas tersebut dapat mempengaruhi kualitas hasil dan kuantitas data yang ada, karena harus melakukan kunjungan rumah semua keluarga di wilayah kerja Puskesmas untuk pendataan PIS-PK dalam kurun waktu yang terbatas dan membagi waktu untuk tugas lainnya. Hal ini terbukti baru satu desa di Puskesmas yang dapat mencapai target total sampling dari target dua desa pada tahun 2017, dan pernyataan sebagai berikut:

"Ada yang harus ulang didatangi lagi....karena itulah gak ikut pelatihan dan memang cuma dijelaskan aja pas kumpul sebelum turun pendataan ke keluarga..cuma sekali itu aja dan ga mungkin semua informasi tersampaikan dengan baik..." (Pendamping Ds. AP, PKM P., Kab. Labuan Batu)

Dalam hal tenaga yang melakukan entry data, Puskesmas merekrut petugas yang mahir menggunakan perangkat komputer dan bisa memahami aplikasi Prokesga (untuk input secara online) dan memahami program excel/SPSS (untuk input data secara manual).

“..untuk petugas input juga kita cari yang sudah mahir supaya tidak terhadap proses input data ke sistemnya.." (Kepala Puskesmas H., Kota Semarang)

Untuk mengatasi keterbatasan sumber daya manusia atau tenaga pengumpul data PIS-PK, Puskesmas melakukan pelatihan kerja lapangan internal Puskesmas terhadap petugas lain yang belum terpapar program PIS-PK, dan menurunkan petugas tersebut untuk membantu pendataan. Selain itu mengerahkan tenaga-tenaga sukarela untuk melakukan pengumpulan data di dua desa yang menjadi target pada tahun 2017. Sebenarnya pemanfaatan tenaga sukarela bisa jadi sebuah strategi yang memadai untuk 
pencapaian target sayangnya tidak disertai dengan kriteria yang jelas, apakah tenaga yang diturunkan adalah tenaga yang terlatih atau terpapar dengan informasi PIS-PK yang komprehensif. Kondisi tersebut, didukung dengan informasi yang diungkapkan informan melalui kutipan wawancara sebagai berikut:

"..sejauh ini sih bisa tetap berjalan dengan baik dengan tenaga yang ada untuk pendataan PIS PK di kota ini..walau memang baru 1-2 Puskesmas yang total sampling, karena gak mungkin juga nakes kita full time untuk puldat yah..karena mereka juga punya tanggung jawab, ada yang jadi perawat, bidan yang ada jam jaga shift nya..mereka harus berbagi tugas dengan tugas-tugas lainnya juga..sejauh ini kita masih memanfaatkan tenaga Puskesmas yang nakes..tidak semua tapi ada beberapa yang tidak pelatihan tapi sudah kita kasih informasi terkait PIS-PK." (Kepala Puskesmas H., Kota Semarang)

Dalam hal frekuensi pelatihan, informan Puskesmas Kabupaten Labuan Batu ataupun di Kota Semarang, diperoleh informasi bahwa pertemuan tersebut hanya dilakukan pada saat akan turun pengumpulan data saja.

\section{Pembiayaan}

Dalam melaksanakan PIS-PK, pembiayaan memiliki peranan yang sangat penting. Puskesmas di Kota Semarang yang menjadi subjek penelitian ini telah memanfaatkan dana BOK untuk melakukan sosialisasi dan promosi kesehatan ke masyarakat sebagai sumber dana pada kegiatan pendataan PIS-PK ke masyarakat, sedangkan Puskesmas di Kabupaten Labuan Batu sama sekali tidak memiliki anggaran untuk operasional pendataan PIS-PK; bahkan informasi pemanfaatan dana BOK untuk pendataan PIS-PK sekaligus untuk penyuluhan ke masyarakat tidak mereka ketahui. Sampai penelitian ini dilakukan, Puskemas masih kesulitan dalam memberikan transpor kepada petugas pengumpul data. Hal ini seperti yang diungkapkan informan dengan kutipan wawancara sebagai berikut :

"Memang kita tidak punya dana khusus untuk pendataan, selama ini petugas kami hanya melakukan pendataan secara sukarela aja sebagai bagian dari tupoksi mereka..saya malah tidak tahu kalau bisa pakai dana BOK..karena tidak ada informasi sampai kesana dari pihak dinkes kabupaten.." (Kepala Puskesmas P., Kab. Labuan Batu).

Pendanaan yang tersedia memang belum mencukupi untuk mendanai kegiatan PIS-PK, seperti transpor dalam pendataan, penggandaan instrumen/kuesioner, Pinkesga dan family folder atau map arsip untuk menyimpan kuesioner untuk masing-masing keluarga yang telah dikunjungi. Dana yang dialokasikan bervariasi tiap Puskesmas, tergantung jumlah keluarga. Walaupun demikian, biaya yang tersedia tersebut memang dirasa masih sangat minim mengingat dalam pendataan yang sesuai prosedur petugas seharusnya melakukan kunjungan lebih dari satu kali, untuk menemui anggota rumah tangga yang tidak dapat ditemui pada saat pendataan; karena semua anggota rumah tangga yang usianya lebih dari lima belas tahun harus diwawancara secara langsung.

Keterbatasan dana ini juga yang kemudian membuat petugas pendata hanya melakukan kunjungan satu kali ke masingmasing keluarga, yang berarti bahwa pengisian kuesioner anggota rumah tangga yang tidak berada di rumah saat pendataan diwakilkan oleh anggota rumah tangga lainnya yang ada di rumah pada saat itu. Selain itu, penggandaan kuesioner masih harus berkoordinasi dengan dinas kesehatan kabupaten dan pada saat tim penlitian ini mengumpulkan data, petugas Puskesmas masih belum mendapatkan pengganti. Hal ini berakibat tidak tercapainya target pendataan. Berikut kutipan wawancaranya:

kali dan memang kebanyakan 1 kali..hambatannya tentu soal dana, memang sih bisa pakai BOK tapi tidak semua bisa diarahkan untuk pengumpulan data PIS PK ini, kita kasih transport yang memang ala kadarnya untuk tenaga pengumpul data yang memang kebetulan nakes kita bekerja sama dengan kader..malah nakes kita juga berbagi ke kadernya entah berapa seiklas mereka saja..karena dana ini belum bisa kita berikan secara maksimal.." (Kepala Puskesmas H., Kota Semarang) 


\section{Alat dan Metode}

Bahan/alat dalam pelaksanaan PIS-PK meliputi kuesioner, PINKESGA, perangkat entry data seperti komputer, jaringan nirkabel dan juga termasuk program aplikasi PROKESGA. Dalam pengumpulan data, instrumen merupakan hal yang paling krusial. Instrumen berupa kuesioner PIS-PK yang telah disusun oleh tim Kementerian Kesehatan.

Pengumpulan data dengan instrumen kuesioner maupun aplikasi PROKESGA program entry data. Untuk keperluan pengumpulan data, kuesioner diperbanyak oleh masing-masing Puskesmas. Pada saat melakukan kunjungan rumah, petugas tidak hanya melakukan pengumpulan data, tetapi sekaligus melakukan penyuluhan, terutama terhadap keluarga yang teridentifikasi memiliki masalah terkait indkator PIS-PK. Alat bantu untuk melakukan penyuluhan adalah PINKESGA berupa leaflet. Kendalanya adalah belum tersedia PINKESGA dengan jumlah yang cukup (sesuai dengan jumlah tenaga pengumpul data). Hal ini berdampak pada tidak dilakukannya intervensi awal di semua rumah tangga yang dikunjungi pada saat pendataan PIS-PK. Intervensi awal dilakukan pada temuan-temuan di rumah tangga tertentu saja yang kebanyakan terkait dengan perilaku merokok. Berikut kutipan wawancaranya:

“...kalau PINKESGA kita punya tapi memang tidak semua petugas karena jumlahnya 50-an petugas yang turun kemarin mengingat target dengan waktu yang terbatas..jadi intervensi awal itu dilakukan memang tapi tidak menyeluruh di semua rumah tangga yah..keterbatasan kita juga itu..kita akui yah.." (PJ PIS-PK PKM P., Kab. Labuan Batu)

Ketersediaan sarana untuk entry dan pengiriman data seperti komputer, jaringan internet di kedua Puskesmas berbeda kondisinya. Puskesmas Halmahera, Kota Semarang yang berlokasi di daerah perkotaan; tidak ada kendala dalam kegiatan entry data. Jaringan internetpun tersedia karena Puskesmas memiliki sistem informasi Puskesmas telah berbasis online. Berikut kutipan wawancaranya:

"Kalau di Puskesmas ini aplikasi sudah ada saat pulang pelatihan, kuesioner tersedia dan cukup jumlah tidak ada masalah lah yah untuk itu semua..jaringan juga kita tersedia malah 24 jam..komputer pun ada 1 khusus untuk entry data karena petugas entry kita juga ada 1 yang khusus..metodenya ya turun ke rumah tangga wawancara dengan kuesioner..sambil penyuluhan sedikit-sedikit kalau ada yang perilakunya beresiko terhadap kesehatannya seperti merokok...tapi gak semua sih laporan dari petugasnya di lakukan penyuluhan karena keterbatasan waktu dan tenaga kita.." (PJ PIS PK PKM H., Kota Semarang)

Berbeda kondisi dengan Puskesmas lainnya, di mana entry dan pengiriman data terkendala oleh tidak tersedianya jaringan internet yang memadai. Proses entry maupun pengiriman data dilakukan di luar Puskesmas (di tempat-tempat yang menyediakan fasilitas internet gratis), seperti rumah makan atau restoran). Dalam kondisi mendesak, petugas menggunakan jaringan internet melalui telepon selular milik pribadi. Berikut kutipan wawancara sebagai pendukung informasi tersebut:

“..kalau untuk jaringan ini jadi kendala juga untuk entry data. Di sini (di Puskesmas) gak ada internet..jadi petugas entry kita janjian ke mana ajalah yang ada fasilitas wi-fi gratisan untuk entry data, kasian juga sih sebenarnya tp itu usaha mereka lah yah..yang walau wi-fi nya gratis tapi tetap saja ada biaya yang dikeluarkan untuk beli minuman agar dapat wi-fi gratis itu..kalau kepepet sekali karena tim litbang mau datang mau tidak mau pakai paket data pribadi mereka untuk koneksi jaringan ke aplikasi.." (PJ PIS- PK PKM P., Kab. Labuan Batu)

\section{Indikator Proses (Process Indicator)}

Proses pada penelitian ini adalah faktor-faktor yang akan dievaluasi meliputi perencanaan (P1), pelaksanaan (P2) dan pengawasan pengendalian dan penilaian (P3) Program Indonesia Sehat dengan Pendekatan Keluarga (PIS PK).

\section{Kabupaten Labuan Batu}

Terkait perencanaan (P1), informasi yang didapatkan dari Puskesmas di Puskesmas terpilih di Kabupaten Labuan Batu 
memiliki kemiripan terkait masalah perencanaan yaitu mereka sama-sama tidak siap untuk melakukan pengumpulan data. Ketidaksiapan dikarenakan informasi yang didapatkan dari dinas kesehatan sangat mendesak, waktu terbatas, sehingga perencanaan tidak dilakukan secara maksimal dan matang. Hal ini seperti yang diungkapkan oleh salah seorang informan:

".. "perencanaan itu cuma dalam sebulan aja sebelum kita turun lapangan..semua memang saya akui serba mendadak..makanya dalam pelaksanaannya saya akui banyak kesalahan yah..(informan tersenyum)..(Informan Kepala PKM P, Labuhan Batu)

Di tengah perencanaan dan persiapan yang terbatas, puskesmas harus menyiapkan kuesioner dan Pinkesga sebagai instrumen untuk melakukan pengumpulan data dan inervensi ke rumah tangga. Sosialisasi berupa pertemuan kepada tenaga pengumpul data hanya dilakukan satu kali, itupun dimanfaatkan untuk persiapan perizinan ke daerah-daerah sulit. Perizinan ke pemukiman warga Nias yang berlokasi di perbukitan dilakukan dengan bantuan aparat militer (tentara) karena ada salah satu pendamping desa yang merupakan istri kepala pasukan ABRI.

Pelaksanaan (P2) pengumpulan data di dua desa terpilih di masing-masing Puskesmas memakan waktu cukup lama, yaitu berkisar antara 4 sampai 8 minggu. Lamanya waktu tersebut tergantung ada tidaknya daerah sulit, dan karakteristik masyarakat desa. Semakin tertutup masyarakat dan karakteristik masyarakat cenderung berpindah-pindah akan memakan waktu lebih lama.

Dari masing-masing Puskesmas yang memiliki target dua desa dengan pendataan total sampling hanya satu desa yang memenuhi target. Satu desa lagi di masingmasing Puskesmas belum terselesaikan. Hal tersebut dikarenakan beberapa masyarakat hidup berpindah-pindah sehingga belum terlacak. Puskesmas bertekad tetap mencari informasi terkait keberadaan rumah tangga tersebut. Data juga belum setengahnya terentry dalam sistem aplikasi Prokesga karena keterbatasan waktu dan hambatan sarana pendukung seperti jaringan internet.
Beberapa temuan dalam pelaksanaan pengumpulan data PIS-PK di Puskesmas Parlayuan Kab. Labuan Batu, antara lain: kesalahan dalam pencatatan di kuesioner dimana petugas Puskesmas mencatat jawaban tidak langsung di kolom yang ada melainkan mencatat di bagian belakang kuesioner yang menurut informasi untuk memudahkan proses entry data, wawancara tidak dilakukan kepada semua anggota keluarga di dalam rumah tangga sehingga jawaban anggota keluarga lainnya diwakilkan oleh yang dapat ditemui saat kunjungan pertama, intervensi awal hanya dilakukan terbatas jika anggota rumah tangga menanyakan tentang masalah kesehatan tertentu atau ditemukan bahwa ada anggota rumah tangga yang merokok, belum dilakukannya upaya kunjungan ulang (follow up) atas temuan kasus-kasus di rumah tangga seperti kasus suspect TB baru yang diakui belum dilakukan kunjungan ulang oleh pemegang program TB karena keterbatasan waktu dan orientasi pelaksanaan pendataan hanya pada terkumpulnya data keluarga secara total sampling, dan data yang dikumpulkan dari rumah tangga sampel pendataan ada beberapa yang tidak valid saat dilakukan kunjungan ulang dalam rangka validasi. Data yang tidak valid tersebut antara lain data indikator kepemilikan JKN, ASI Eksklusif dan pemantauan tumbuh kembang balita yang tidak sesuai antara kondisi sebenarnya di anggota rumah tangga dan jawaban dalam kuesioner. Bahkan dari penelitian ini ditemukan bahwa ternyata sebagai salah seorang petugas Puskesmas pun belum pernah mengetahui dan melihat kuesioner isian PISPK. Keterbatasan dalam pelaksanaan pendataan terungkap dari salah seorang informan berikut:

“...tapi untuk turun ke lapangan memang belum pernah dan melihat kuesioner isian mereka-pun memang belum pernah..mungkin nanti.."(Informan Kepala Puskesmas P., Labuan Batu)

Dalam pengawasan (P3), diakui oleh informan Puskesmas yang menjadi subjek penelitian bahwa selama ini belum ada mekanisme monitoring evaluasi baik internal Puskesmas oleh kepala Puskesmas maupun dalam relasi vertikal dari Dinas Kesehatan kabupaten/kota setempat. Hal ini seperti yang diungkap informan penelitian dengan kutipan wawancara sebagai berikut: 
“..itulah keterbatasan kita.. kalau pengawasan selama proses pendataan memang tidak ada dari dinas kesehatan kabupaten..kalau saya cuma sekedar dengar kalau ada informasi dari petugas.." (Informan Kepala Puskesmas P, Kab. Labuan Batu).

\section{Kota Semarang}

Terkait perencanaan (P1), informasi yang didapatkan dari Puskesmas di 2 Puskesmas terpilih di Kota Semarang juga memiliki kemiripan terkait masalah perencanaan yaitu mereka sama-sama memiliki kesiapan dan perencanaan yang baik untuk melakukan pengumpulan data. Pengumpulan data dilakukan secara terencana dan dijadwalkan selesai dalam waktu 3 bulan. Pada tahap perencanaan Puskesmas melakukan koordinasi dengan lintas sektor yaitu lurah dan camat serta ketua RW dan RT setempat dalam acara mini lokakarya sambil mensosialisasikan kegiatan PIS PK di Kota Semarang. Puskesmas menyiapkan kuesioner dan pinkesga sebagai instrumen untuk melakukan pengumpulan data ke rumah tangga dan sosialisasi pertemuan ke tenaga pengumpul data yang dilakukan 1-2 kali. Terkondisikannya perencanaan Puskesmas untuk kegiatan PIS-PK terungkap dari salah seorang informan berikut:

“..."perencanaan sudah dilakukan beberapa bulan sebelum turun pendataan, kita pastikan bahwa pendamping harus tahu apa itu pendekatan keluarga dan bagaimana mekanisme pengumpulan datanya..(Informan Puskesmas H, Kota Semarang)

Pelaksanaan (P2) pengumpulan data di 2 Kelurahan terpilih di masing-masing Puskesmas memakan waktu relatif sama yaitu sekitar 2 bulanan ( 8 minggu) namun ini masih sesuai dengan perencanaan pelaksanaan pendataan di awal kegiatan. Hambatan utama pelaksanaan pengumpulan data lebih kepada beban kerja tenaga Puskesmas yang besar. Terlebih tenaga kesehatan masih harus bekerja berdasarkan pembagian shift di pelayanan Puskesmas. Sehingga pengumpulan data dilakukan disela-sela waktu kosong tenaga kesehatan yang bertugas melakukan pengumpulan data. $\mathrm{Di}$ masing-masing kelurahan terdapat 1 pendamping yang bertanggungjawab terhadap pelaksanaan pendataan PIS PK. Dalam pelaksanaan pendataan tenaga kesehatan dibantu oleh kader dalam mendata rumah tangga.

Dari masing-masing Puskesmas yang memiliki target 2 kelurahan dengan pendataan total sampling, keduanya berhasil memenuhi target pendataan dan data sebagian besar sudah di-entry ke dalam sistem aplikasi Prokesga. Ada beberapa data yang belum ter-entry kedalam aplikasi karena masih perlu dilakukan validasi terhadap kuesioner tersebut sebagai bentuk pengawasan kualitas data oleh Puskesmas.

Temuan dalam pelaksanaan pengumpulan data PIS-PK di Kota Semarang, antara lain: wawancara tidak dilakukan kepada semua anggota keluarga didalam rumah tangga sehingga jawaban anggota keluarga lainnya diwakilkan oleh yang dapat ditemui saat kunjungan pertama, intervensi awal hanya dilakukan terbatas jika anggota rumah tangga menanyakan tentang masalah kesehatan tertentu atau ditemukan bahwa ada anggota rumah tangga yang merokok, data yang dikumpulkan dari rumah tangga sampel pendataan masih ada beberapa yang tidak valid saat dilakukan kunjungan ulang dalam rangka validasi antara lain dalam indikator kepemilikan JKN, ASI Eksklusif dan pemantauan tumbuh kembang balita yang tidak sesuai antara kondisi sebenarnya di anggota rumah tangga dan jawaban dalam kuesioner. Temuan pelaksanaan di lapangan dimana petugas melibatkan aparat setempat terungkap dari kutipan jawaban salah seorang informan berikut:

“...kita awalnya rencanakan 3 bulan kurang lebih untuk pendataan..tapi dalam 2 bulan 1 desa bisa terpenuhi targetnya total sampling karena kita udah koordinasi dengan $R T R W$ dan Lurah setempat sehingga petugas bisa masuk ke masyarakat dengan lebih mudah, dari awal kita juga ajak kader bekerja sama untuk memudahkan petugas kita masuk ke rumah tangga..karena kader itu kan lebih dekat ke masyarakat yah.." (Informan Puskesmas H, Kota Semarang)

Terkait pengawasan (P3), diakui oleh kedua Puskesmas yang menjadi subjek penelitian bahwa selama ini pihak dinas kesehatan yaitu PJ PIS-PK Dinkes Kota Semarang sudah pernah melakukan monitoring evaluasi ke Puskesmas untuk memastikan 
pelaksanaan pendataan PIS-PK di puskesmas berjalan sesuai rencana. Hal ini seperti yang diungkap informan penelitian dengan kutipan wawancara sebagai berikut:

“..monitoring dari dinkes berjalan tapi untuk evaluasi memang belum sampai saat ini...penanggung jawab PIS PK nya beberapa kali datang untuk memantau progress pendataan.." (Kepala Puskesmas H., Kota Semarang)

\section{Indikator Hasil (Output Indicator)}

Secara umum, output dari pendataan PIS-PK di kedua kabupaten/kota adalah tercapainya pendataan seluruh rumah tangga di dua desa dari masing-masing puskesmas terpilih. Pada kenyataannya, untuk Puskesmas P Kabupaten Labuan Batu masih terdapat beberapa rumah tangga yang belum teridentifikasi keberadaannya. Selain itu output dalam hal entry data ke dalam sistem Prokesga sudah dilakukan di Kota Semarang, namun di Kabupaten Labuan Batu hanya sebagian data yang telah di-entry dalam sistem aplikasi Prokesga.

Hasil pendataan PIS PK di masingmasing Puskesmas di Kabupaten terpilih, dapat dilihat pada Tabel 1 dibawah ini mengenai persentasi pencapaian 12 indikator PIS PK berdasarkan konfirmasi dan kunjungan program di Kabupaten Labuan Batu dan Kota Semarang sebagai berikut:

Tabel 1. Persentase Pencapian 12 Indikator PIS PK Berdasarkan Konfirmasi dan Kunjungan Progam Pada Kab.Labuhan batu dan Kota Semarang Tahun, 2017

\begin{tabular}{lrrrr}
\hline \multirow{2}{*}{ INDIKATOR } & \multicolumn{4}{c}{ KABUPATEN/KOTA } \\
\cline { 2 - 5 } & \multicolumn{1}{c}{ Kabupaten Labuhan Batu } & \multicolumn{2}{c}{ Kota Semarang } \\
\cline { 2 - 5 } & Progam & Konfirmasi & Progam & Konfirmasi \\
\hline KB & 21,36 & 23,30 & 43,75 & 55,07 \\
Lahir Fasyankes & 100,00 & 100,00 & 50,00 & $100,00^{*}$ \\
Imunisasi & 63,64 & 71,43 & 100,00 & 100,00 \\
ASI & 41,67 & 37,50 & 100,00 & 71,43 \\
Tumbang Balita & 55,88 & $76,92^{*}$ & 90,91 & 100,00 \\
TB Paru & 25,00 & $58,33^{*}$ & 0,00 & 66,67 \\
Hipertensi & 33,33 & 31,82 & 46,15 & 40,63 \\
Gangguan Jiwa & 100,00 & $0,00^{*}$ & 0,00 & 0,00 \\
Merokok & 34,55 & 26,36 & 35,59 & 37,08 \\
JKN & 28,18 & 28,18 & 55,93 & 59,55 \\
Air Bersih & 95,45 & 88,18 & 93,22 & 88,76 \\
Jamban & 96,36 & 98,18 & 94,92 & 96,63 \\
Nilai IKS & 0,04 & 0,06 & 0,24 & 0,29 \\
\hline
\end{tabular}




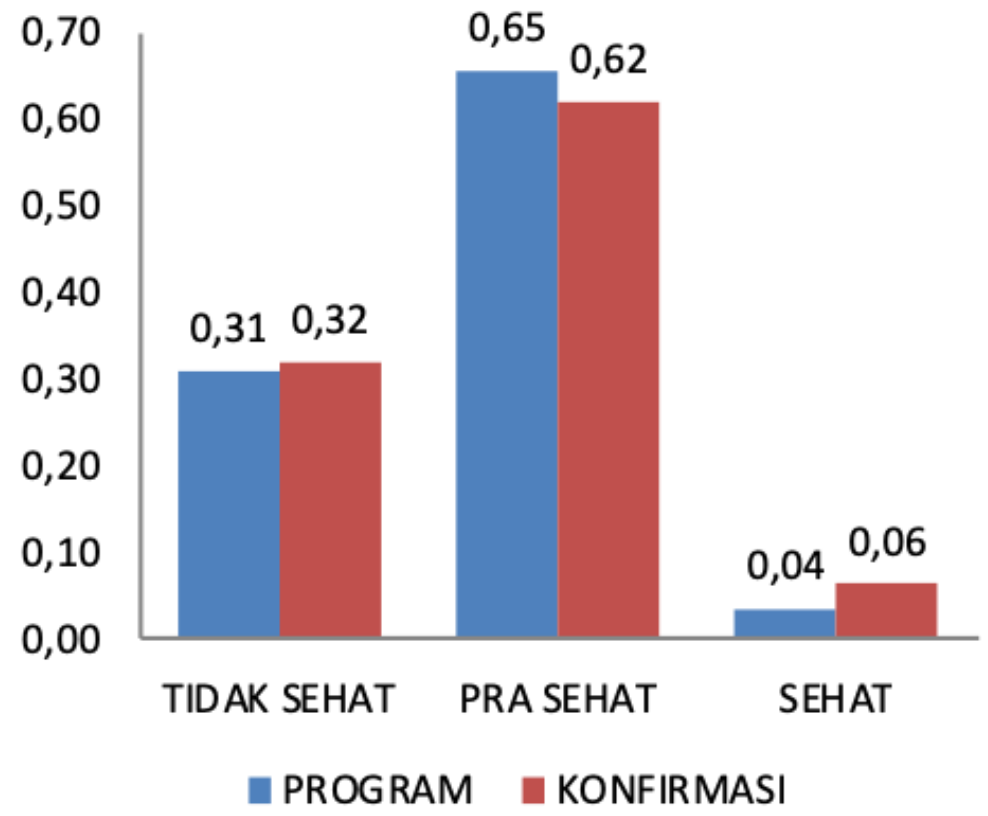

Gambar 1a. Nilai IKS Konfirmasi dan Kunjungan Progam PIS PK Pada Kabupaten Labuhan Batu Tahun, 2017

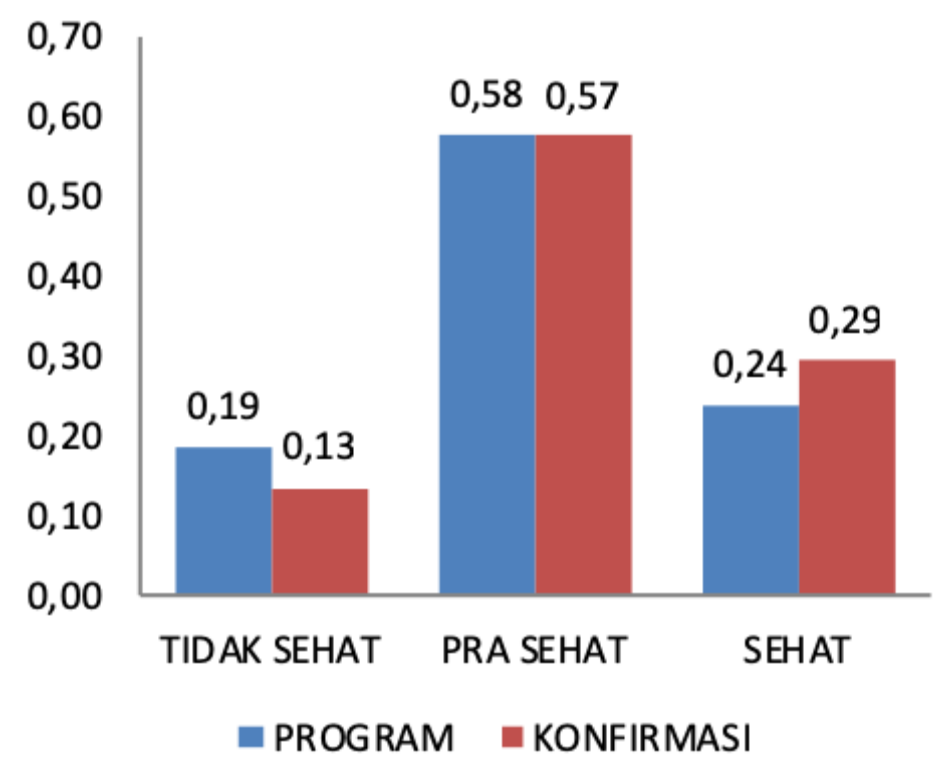

Gambar 1b. Nilai IKS Konfirmasi dan Kunjungan Progam PIS PK Pada Kota Semarang Tahun, 2017 
Dari tabel 1 dan gambar $2 \mathrm{a}$ dan $2 \mathrm{~b}$ diatas terlihat pencapaian cakupan 12 indikator bervariasi antara kunjungan program dengan kunjungan konfirmasi. Perbedaan cakupan antara kunjungan progam dan konfirmasi hampir semua indikator tidak terlalu jauh. Terdapat 3 indikator yang perbedaannya sedikit jauh (berkisar 10 persen atau lebih) untuk Kabupaten Labuhan Batu yaitu indikator Tumbuh Kembang Balita, TB Paru, dan Gangguan Jiwa Berat, sementara untuk Semarang ada 4 indikator yaitu KB, melahirkan di Fasyankes, ASI, dan TB Paru.

Walaupun cakupan ini sama-sama $100 \%$ belum tentu menggambarkan jumlah responden yang sama, namun pola perhitungan indikatornya sudah sama yaitu seluruh kasus yang ditemukan ditangani sesuai standar. Bila kita melihat capaian indikator berdasarkan konfirmasi Semarang lebih bagus dari Labuhan Batu. Di Kota Semarang capaian indikator dibawah 50 persen hanya ada 3 indikator (Hipertensi, Gangguan Jiwa, Merokok), sementara di Labuhan Batu ada 6 indikator (KB, ASI, Hipertensi, Gangguan Jiwa, Merokok, JKN). Ada perbedaan antara IKS yang dilakukan oleh program dengan konfirmasi di Kabupaten Labuhan Batu dan di Kota Semarang.

Khusus untuk empat indikator KIA (KB, Lahir di Fasyankes, Imunisasi, dan ASI Eksklusif) persentase pencapian keempat indikator tersebut Semarang relative lebih bagus daripada Labuhan Batu, baik pencapaian progam maupun konfirmasi. Hanya Indikator lahir di Fasyankes untuk Semarang baru 50\% dibanding Labuhan Batu yang sudah $100 \%$.

Salah satu tujuan dari evaluasi ini adalah untuk mengetahui perbedaan nilai IKS, cakupan indikator antara kunjungan progam dan kunjungan konfirmasi serta permasalahan yang ada. Dalam analisa kami menjejerkan antara nilai kunjungan progam dan konfirmasi. Pada kenyataannya tidak semudah itu karena beberapa kendala. Kendala tersebut antara lain, wawancara yang seharusnya dilakukan terhadap semua anggota keluarga yang masuk kriteria, ternyata sebagian besar diwakilkan hanya kepada satu orang (Labuhan Batu), tidak dilakukan pengukuran tekanan darah (data tekanan darah berdasarkan jawaban responden yang kadang juga diwakilkan), sehingga dalam analisis kesulitan membedakan nilai yang seharusnya. Oleh karena itu dalam hasil cakupan indikator ada perbedaan nilai cakupan indikator program dengan konfirmasi dan antar daerah.

Secara manual masing-masing puskesmas di 2 kabupaten/kota tersebut juga melakukan input manual menggunakan program microsoft excel untuk melihat data awal hasil pendataan PIS-PK. Hal tersebut dilakukan karena pada periode Juni Agustus 2017 aplikasi dan server Prokesga sempat mengalami masalah (sangat sulit untuk bisa masuk kedalam sistem kecuali tengah malam), sehingga Puskesmas berinisiatif untuk melakukan input data secara manual. Namun pembacaan IKS secara manual dan melalui perhitungan sistem aplikasi Prokesga akan sangat berbeda.

Kepala puskesmas subjek penelitian di Kota Semarang menyatakan bahwa data IKS (output) yang terkumpul dari hasil pendataan akan digunakan sebagai pedoman dalam menyusun program puskesmas di tahun yang berikutnya, berdasarkan masalah kesehatan yang ditemukan di masing-masing kelurahan/desa. Selain itu hasil IKS diinformasikan juga kepada lurah setempat, pada saat lokakarya mini tiga bulanan. Intervensi yang dilakukan tergantung dari temuan dari hasil pendataan, seperti pembuatan jamban untuk keluarga miskin yang belum memiliki jamban, dan pembuatan jamban umum. Berbeda dengan puskesmas di Kota Semarang, puskesmas di Kabupaten Labuan Batu, menyatakan bahwa belum berani memanfaatkan data IKS sebagai dasar penyusunan program kerja puskesmas, karena selain belum disosialisasikan secara lintas sektoral juga karena belum seluruhnya data hasil pendataan PISPK dilakukan entry kedalam aplikasi Prokesga, dan belum dilakukannya validasi terhadap beberapa kuesioner hasil pendataan.

\section{PEMBAHASAN}

Salah satu input dalam PIS-PK adalah tenaga pelaksana. Berdasarkan hasil 
wawancara mendalam, hampir seluruh informan menyatakan bahwa tenaga pelaksana belum memadai kualitasnya. Hal ini karena dalam pelaksanaannya pendataan PIS-PK tidak hanya melibatkan petugas puskesmas yang telah mendapatkan pelatihan, tetapi melibatkan hampir semua petugas di puskesmas termasuk yang belum mendapatkan pelatihan, dan kader yang tidak memiliki latar belakang kesehatan untuk melakukan pengumpulan data PIS-PK. Selain itu tenaga puskesmas yang ditugaskan dalam PIS-PK pada umumnya bukan tenaga khusus, melainkan tenaga yang telah ditugaskan menangani program lain (gizi, kesehatan lingkungan, KIA). Kondisi ini berpengaruh terhadap kualitas hasil pendataan, terbukti adanya perbedaan cakupan indikator Tumbuh Kembang Balita, TB Paru, dan Gangguan Jiwa Berat (Puskesmas P., Kabupaten Labuhan Batu) dan indikator, KB, melahirkan di Fasyankes, ASI, dan TB Paru (Puskesmas H., Kota Semarang). Ketidak siapan tenaga PIS-PK tersebut, tidak hanya terjadi kedua lokasi penelitian. Hal ini terjadi juga Kota Depok. Hasil penelitian Ernawati dan Adang tahun 2018, menyatakan bahwa sumber daya manusia (SDM) untuk persiapan implementasi PIS-PK dari segi kuantitas yang tersedia di kota Depok masih kurang untuk (Ernawati Roesli, 2018)

Salah satu upaya untuk mengatasi kurangnya tenaga kunjungan rumah (pendataan) PIS-PK di beberapa daerah sulit, dapat memanfaatkan tenaga Nusantara Sehat. Nusantara Sehat adalah progam pemerintah untuk pemerataan tenaga kesehatan di daerah sulit dengan sistem kontrak selama dua tahun. Tenaga Nusantara Sehat dapat diperbantukan dalam kegiatan PIS-PK, karena pada saat pembekalan diberikan materi tentang PIS-PK. sudah sejak awal (sebelum keberangkatan ke tempat tugas) sudah dibekali dengan apa dan bagaimana PIS-PK; sehingga tenaga ini sudah siap membantu. Dengan tenaga Nusantara Sehat, ternyata tidak menyelesaikan permasalahan pelaksanaan PIS-PK di puskesmas, karena tenaga Nusantara Sehat juga tidak spesifik ditugaskan untuk membantu pelaksanaan PIS-PK, melainkan membantu seluruh program di puskesmas.
Adanya tenaga pelaksana program terlatih merupakan salah satu indikator yang penting dalam keberhasilan program. Pelatihan merupakan upaya strategis dalam menyiapkan tenaga terlatih, karena secara teori pelatihan merupakan proses mengajarkan keahlian dan memberikan pengetahuan yang sesuai keperluan, serta sikap agar dapat melaksanakan tanggung jawabnya sesuai dengan standar yang ditetapkan (Cushway and Lodge, 1999). Dengan demikian, untuk mengatasi keterbatasan ketersediaan tenaga, dapat dilakukan dengan merekrut tenaga yang sesuai dengan kebutuhan dalam setiap tahapan kegiatan. Tenaga yang direkrut tersebut, diberi pembekalan/dilatih, agar bekerja sesuai dengan standar yang ditetapkan.

Pemanfaatan tenaga diluar kualifikasi yang sesuai dengan PIS-PK bisa berdampak pada kualitas data yang dihasilkan, dan SOP untuk melakukan intervensi awal kemungkinan tidak dijalankan; karena selain kurangnya pengalaman dalam implementsi PIS-PK, juga karena petugas tidak mendapatkan informasi tentang PIS-PK secara utuh. Petugas cenderung mengabaikan ketentuan metode pendataan yang ditentukan dalam pedoman implementasi PIS-PK sesuai dengan yang ditetapkan dalam pedoman yang dikeluarkan oleh Kementerian Kesehatan; dimana wawancara harus dilakukan terhadap setiap anggota rumah tangga dan diperiksa langsung tanpa diwakilkan; sehingga metode kunjungan rumah tangga mungkan dilakukan berulangkali sampai selutuh anggota rumah tangga terdata. Petugas pendataan diharapkan melakukan kunjungan rumah secara rutin untuk memperbaharui data, menjaga data tetap mutakhir walaupun terjadi perubahan-perubahan, seperti adanya keluarga pindah, perubahan status ART, seperti lahir/mati, dan lain-lain menikah.

Penanggung jawab PIS-PK di Puskesmas yang telah mengikuti pelatihan PIS-PK diharapkan dapat menjalankan program sesuai dengan otoritas jabatan dan kecakapan/keahlian yang mereka miliki. Latar belakang pendidikan kesehatan yang mereka miliki dan program di Puskesmas yang mereka pegang selama ini 
bersinggungan langsung dengan indikator yang ada pada PIS-PK (koordinator bidan, kesehatan lingkungan, promosi kesehatan).

Dilihat dari latar belakang pendidikannya, sebagian tenaga pendata PISPK yang merupakan tenaga kesehatan sudah sesuai dengan aturan formal yang tertuang dalam Permenkes nomor 39 tahun 2016; yang menyatakan bahwa tenaga pengumpul data PIS-PK merupakan tenaga kesehatan Puskesmas yang bertugas untuk memberikan informasi kesehatan sesuai dengan indikator PIS-PK, dan melakukan penyuluhan kesehatan sebagai salah satu bentuk intervensi awal terhadap keluarga sasaran. Hanya saja beban kerja Puskesmas yang besar. Penambahan tugas sebagai pelaksana PIS-PK, menambah beban kerja para petugas kesehatan di puskesmas; sehingga menjadikan pengumpulan data PIS-PK sebagai tugas tambahan. Untuk mengejar target yang ditetapkan oleh dinkes provinsi dan Kementerian Kesehatan, kebijakan alternatif yang dapat diambil adalah dengan memanfaatkan tenaga sukarela baik dilingkungan internal puskesmas maupun rekrutmen tenaga dari lingkungan eksternal Puskesmas menjadi strategi yang ditempuh untuk mengatasi hambatan dalam hal SDM.

Hal tersebut masih terjadi sampai dengan tahun 2018, yang ditunjukkan oleh hasil penelitian Eva Laelasari dkk yang menemukan bahwa petugas melakukan pengumpulan data PIS-PK setelah selesai melaksanakan pekerjaan di (purna waktu). Temuan penelitian tersebut juga menyatakan bahwa dalam pengumpulan data, petugas puskesmas dibantu oleh tenaga kesehatan sukarela yang belum dilatih secara formal oleh Kementerian Kesehatan. (Eva Laelasari, dkk 2017). Dalam hal rekrutmen terhadap tenaga pengumpul data, telah diatur dalam Permenkes 39 tahun 2016, yang mana Puskesmas dapat bekerjasama secara lintas sektor dengan institusi lain atau merekrut tenaga untuk pengumpul data PIS-PK selama syarat terpenuhi. Adapun syarat petugas pengumpul data PIS-PK minimal D3 kesehatan, sudah mendapatkan pelatihan PISPK baik dari Kementerian Kesehatan, maupun dari Dinas Kesehatan Provinsi atau Kota sesuai dengan Permenkes Nomor 39 Tahun 2016 tentang Pedoman
Penyelenggaraan Program Indonesia Sehat dengan Pendekatan Keluarga (Kementerian Kesehatan RI, 2016). Sayangnya, hasil temuan studi ini menunjukkan bahwa pelatihan yang diberikan untuk tenaga pengumpul data PIS-PK masih sangat terbatas jumlahnya, sehingga 1 Puskesmas hanya mengirimkan 3-5 tenaga Puskesmas untuk mendapatkan pelatihan PIS-PK, sedangkan tenaga yang dibutuhkan untuk melakukan pengumpulan data secara total sampling dan kurun waktu tertentu bisa mencapai puluhan orang. Upaya on the job training (OJT) tenaga Puskesmas lainnya yang akan membantu pengumpulan data PISPK juga tidak serta merta memberikan transfer ilmu yang berkualitas. Hal ini terbukti dari masih ditemukannya kesalahankesalahan dalam pengumpulan data PIS-PK di 2 Puskesmas sampel di 2 kabupaten/kota yaitu Labuan Batu dan Semarang. Sebaiknya, OJT pada tenaga pengumpul data PIS-PK yang belum pernah mendapatkan pelatihan dilakukan dibawah supervise Dinas Kesehatan Kabupaten (Badan Penelitian dan Pengembangan Kesehatan Kementerian Kesehatan RI 2017).

Selain tenaga pelaksana program, pendanaan memiliki peranan penting dalam terlaksananya program kesehatan, dukungan dana yang tidak memadai cenderung menghambat berjalannya program salah satunya tidak tercapainya target sasaran program kesehatan tersebut. Terhambatnya proses pendataan PIS-PK ditingkat rumah tangga, tidak lepas dari masalah alokasi dana. Dari hasil wawancara mendalam di tingkat kabupaten/kota diperoleh informasi bahwa secara operasional kegiatan PIS-PK di puskesmas menggunakan berbagai sumber pembiayaan yang ada, seperti anggaran pendapatan belanja daerah (APBD, dana kapitasi JKN (dari 40\% untuk dukungan operasional), dan dana dari biaya operasional kesehatan (BOK) dalam dana alokasi khusus (DAK) fisik dan non fisik anggaran dana desa (ADD). Hal ini bukan berarti seluruh sumber dana tersebut secara utuh ditujukan untuk operasional pelaksanaan PIS-PK, akan tetapi terintegrasi dengan pembiayaan operasional program lain. Faktanya, penggunaan sumber pendanaan tersebut untuk operasional PIS-PK mengalami kesulitan, karena perlu adanya 
penyesuaian/revisi waktu cukup lama.

Terkait dengan dana untuk pelaksanaan PIS-PK di Puskesmas, dana BOK dan BLUD yang telah diterima oleh Puskesmas sebesar 50 juta rupiah setiap tahunnya. Jumlah ini digunakan untuk berbagai kegiatan puskesmas yang sifatnya promotif dan preventif, sehingga puskesmas merasa sangat kekurangan; karena harus memenuhi berbagai kegiatan puskesmas termasuk untuk operasional pengumpulan data PIS-PK. Biaya yang dikeluarkan untuk operasional PIS-PK sendiri terdiri dari biaya pertemuan sosialisasi kegiatan, biaya pengadaan kuesioner dan pinkesga serta biaya transport petugas untuk kunjungan rumah tangga.

Pentingnya pendanaan dalam PIS-PK juga ditunjukkan oleh hasil studi (Sulistiyowati, 2017; Virdasari, Arso and Fatmasari, 2018b); yang menunjukkan bahwa pendanaan merupakan aspek yang sangat penting dan krusial untuk menunjang pelaksanaan pendataan PIS-PK di Puskesmas. Dana mempengaruhi pelaksanaan pengumpulan data PIS-PK karena berkaitan dengan kelancaran pendataan (pengadaan bahan kuesioner, pengadaan Pinkesga sebagai alat bantu intervensi awal dan transport petugas) serta proses input data hasil kunjungan rumah tangga (sarana seperti komputer/laptop dan sinyal internet). Prokesga secara online pada waktu-waktu tertentu terganggu karena kesulitan akses internet, juga menghambat pelaksanaan PIS-PK yang dilakukan oleh puskesmas.

Puskesmas terkesan tertutup dan sangat berhati-hati dalam menggunakan dana BOK untuk transportasi tenaga pengumpul data. Bahkan hasil penelitian ini menunjukkan bahwa di kabupaten Labuan Batu baik Puskesmas maupun Dinas Kesehatan Kabupaten tidak mengetahui bahwa dana BOK bisa dimanfaatkan untuk mendukung PIS PK dengan memberikan transport pada tenaga pengumpul data. Hal ini sesuai dengan Permenkes nomor 19 tahun 2017 dimana Dana BOK Puskesmas dapat diberikan kepada petugas Puskesmas yang melakukan kunjungan ke masyarakat (termasuk untuk pendataan PIS-PK dengan mengunjungi rumah tangga/keluarga). Penelitian lainnya yang dilakukan oleh Agustina pada tahun 2018 yang menunjukkan bahwa dana BOK dapat dimanfaatkan juga untuk mendukung kegiatan pengumpulan data dengan memberikan transport tenaga pengumpul data PIS-PK sekalipun tenaga kesehatan kontrak atau honorer yang telah diberikan pelatihan. (Agustina, Trisnantoro and Handono, 2019)

Sesuai dengan Permenkes nomor 19 tahun 2017 tentang pedoman pendanaan PISPK, yang menyatakan bahwa untuk pengadaan sarana dan prasarana dapat memanfaatkan dana BLUD Puskesmas untuk bahan habis pakai dan inventaris Puskesmas. Bahan yang dibutuhkan sesuai dengan pedoman pelaksanaan PIS-PK antara lain kuesioner, PINKESGA, family folder, komputer/laptop, sinyal internet untuk input dan pengiriman data. Namun pada pelaksanaannya keterbatasan bahan dan alat ini juga menjadi kendala utama yang dirasakan dalam pendataan PIS-PK, khususnya di kabupaten Labuan Batu dan Kota Semarang. Salah satunya karena jumlah tensimeter dan tim yang turun untuk pendataan tidak sebanding sehingga tidak semua anggota rumah tangga di ukur tensi darahnya dan hanya ditanyakan oleh tenaga Puskesmas kepada anggota rumah tangga atau mengisikannya sendiri. Selain tensimeter sarana lain yang diperlukan untuk mendukung.

Keterbatasan sarana/prasarana ini juga disebabkan karena keterbatasan dana yang bisa dipergunakan untuk pengadaan alat dan bahan. Temuan penelitian ini terkait kendala sumber daya materil penunjang pelaksanaan pendataan PIS-PK sejalan juga dengan penelitian yang dilakukan di Kota Depok pada tahun 2018. (Roeslie, 2018) Selain itu, perihal pendanaan dalam pelaksanaan program PIS-PK tidak hanya terkait pada proses pendataan saja tapi juga pada implementasi pelaksanaan intervensi kesehatan yang ada setelah data PIS-PK dianalisa oleh puskesmas dan penelitian ini tampak menggambarkan bahwa sebagian besar puskesmas subjek penelitian hanya mempersiapkan pendanaan untuk pengumpulan data saja padahal pendanaan untuk intervensi juga perlu direncanakan 
sejak awal. Hal ini sejalan dengan temuan penelitian yang dilakukan di Kota Depok yang menunjukkan hasil bahwa jika puskesmas tidak merencanakan pengumpulan data dengan baik dengan pendanaan yang baik maka untuk pelaksanaan intervensi pun akan terhambat kedepannya. (Astuti and Soewondo, 2019)

Puskesmas sebagai pelaksana PISPK diharapkan dapat melakukan serangkaian kegiatan lainnya, selain melakukan pendataan kesehatan keluarga menggunakan aplikasi Prokesga oleh pembina keluarga (tenaga kesehatan Puskesmas dan pendamping wilayah), yaitu antara lain membuat dan mengelola pangkalan data Puskesmas oleh pengelola data Puskesmas, melakukan analisa hingga merumuskan langkah intervensi masalah kesehatan yang akan diimplementasikan dalam rencana kerja Puskesmas oleh pimpinan Puskesmas, melakukan penyuluhan-penyuluhan melalui kunjungan rumah oleh pendamping wilayah/pembina keluarga, melaksanakan pelayanan kesehatan (baik di dalam maupun diluar gedung) oleh tenaga profesional Puskesmas, serta melaksanakan sistem informasi dan pelaporan Puskesmas oleh tenaga pengelola data Puskesmas.

Metode kunjungan rumah secara total coverage dalam pelaksanaan PIS-PK di Puskesmas masih merupakan salah satu cara terbaik yang bisa dilakukan oleh Puskesmas untuk meningkatkan jangkauan sasaran dan mendekatkan serta meningkatkan akses pelayanan kesehatan di wilayah kerjanya, namun tentu harus dengan pelaksanaan yang sesuai dengan SOP yang diharapkan oleh Kementerian Kesehatan yaitu melakukan wawancara untuk setiap anggota rumah tangga tanpa diwakilkan.

Terkait dengan indikator proses, Puskesmas kota Semarang telah melakukan implementasi kegiatan PIS-PK melalui tahapan P1, P2, dan P3 sesuai dengan pedoman yang ada. Perencanaan matang penting dilakukan jauh sebelum pengumpulan data guna mengidentifikasi semua faktor pendukung dan penghambat serta mencari solusi agar pendataan dapat terealisasi sesuai target. Berbeda dengan proses yang berlangsung di Kabupaten Labuan Batu, dimana pendataan PIS-PK kurang direncanakan dengan baik, sehingga target pendataan tidak bisa terpenuhi karena timbulnya berbagai kendala di lapangan. Perencanaan yang baik tidak terlepas dari peran aktif dan komitmen dari dinas kesehatan dan Puskesmas sebagai ujung tombak. Hal ini juga sesuai dengan hasil penelitian yang dilakukan oleh (Eva Laelasari et al. 2019) di Puskesmas Purwoyoso, Semarang, dimana implementasi PIS-PK telah sampai pada tahap intervensi kesehatan. Keberhasilan Puskesmas Purwoyoso tidak lepas dari komitmen, dukungan, dan monitoring dari dinas kesehatan sehingga PIS-PK dapat terlaksana dengan baik sesuai perencanaan dengan memaksimalkan sumber daya yang ada (Eva Laelasari et al., 2019).

Pelaksanaan PIS-PK yang dilakukan di beberapa kabupaten kota termasuk kota Semarang dan Kabupaten Labuhan Batu memang belum sepenuhnya berjalan dengan baik. Masih banyak permasalahanpermasalahan yang timbul di lapangan mulai dari masalah yang terkait dengan instrumen (kuesioner), ketidaktepatan dalam pengisian kuesioner oleh petugas pendata sebagai akibat pelibatan tenaga pengumpul data yang belum mendapatkan pelatihan PIS-PK (bahkan ada yang menggunakan tenaga kader/tenaga swadaya lainnya sebagai tenaga pengumpul data, padahal hal ini tidak diperkenankan), tidak dilakukannya intervensi awal pada keluarga yang teridentifikasi memiliki masalah kesehatan, hingga ketiadaan dana sebagai akibat dari minimnya informasi yang diterima oleh pihak dinas kesehatan untuk bisa mengarahkan puskesmas agar memanfaatkan pos-pos keuangan di puskesmas seperti Dana BOK dalam memfasilitasi pelaksanaan pendataan PIS-PK di wilayah kerja mereka masing-masing. Permasalahan-permasalahan tersebut pada akhirnya dapat mempengaruhi baik langsung maupun tidak langsung terhadap kualitas data yang didapatkan selama pengumpulan data PIS-PK ditingkat keluarga.

Temuan penelitian ini terkait hambatan dalam pelaksanaan pendataan PISPK juga sejalan dengan beberapa penelitian terkait evaluasi PIS-PK yang telah dilakukan antara lain kurangnya pengetahuan tenaga 
pengumpul data karena belum mendapatkan pelatihan dan juga karena kekurangan tenaga pendata akibat beban kerja puskesmas yang sudah besar, sehingga berakibat pada tidak dilakukannya intervensi awal akibat ketiadaan supervisi atau pengawasan dari pemegang program terkait. (Virdasari, Arso and Fatmasari, 2018)

Selain itu, kurangnya kerjasama lintas sektor dalam PIS-PK ini sangat tampak dari minimnya informasi yang diterima aparat desa atau kelurahan mengenai pelaksanaan pendataan PIS-PK, padahal salah satu tujuan dari PIS-PK ini adalah menyelesaikan masalah-masalah kesehatan yang ada di masyarakat sesuai dengan 12 indikator yang ada dan beberapa diantaranya sangat memerlukan kerjasama lintas sektor untuk melakukan intervensi lanjutan seperti pengadaan jamban atau WC sehat bagi daerah yang diketahui tidak memiliki jamban dan WC sehat serta intervensi kepemilikan kartu BPJS atau jaminan kesehatan lainnya bagi masyarakat yang tidak memilikinya. Intervensi-intervensi tersebut tidak bisa hanya dilakukan oleh pihak puskesmas seorang diri, melainkan harus melibatkan lurah, kepala desa dan bupati pada tingkat yang lebih tinggi.

Dalam hal dukungan teknologi informasi seperti perangkat komputer, wi-fi, program aplikasi online baik ditingkat daerah dalam hal ini di puskesmas sebagai pelaksana kegiatan PIS-PK dan ditingkat pusat yaitu kementerian kesehatan sebagai pengelola aplikasi ditingkat pusat belum sepenuhnya mendukung kelancaran pelaksanaan program PIS-PK. Hambatan terbesar adalah sulitnya mengakses aplikasi online pada jam kerja dan kondisi ini diperparah dengan terbatasnya sarana dan prasarana teknologi untuk melakukan entry data di daerah. Hal ini juga sehalan dengan temuan penelitian yang dilakukan di kota Bogor bahwa dukungan teknologi informasi dalam pelaksanaan pengumpulan data PIS-PK sangatlah penting dan jika tidak di persiapkan secara baik justru akan menjadi penghambat yang signifikan. (Fauzan, Chotimah and Hidana, 2019)

Sebaiknya hasil pendataan ditindaklanjuti dengan kerjasama lintas program. Berdasarkan hasil pendataan KS di Semarang maka dibuatlah prioritas masalah berdasarkan penghitungan KS yaitu, urutan pertama TB Paru selanjutnya Merokok, Gangguan Jiwa, JKN, dan ASI Eksklusif.

Dari hasil pendataan KS, Puskesmas membuat Rencana Aksi Daerah (RAD) misalnya melakukan Survei Mawas Diri (SMD). Setelah membuat prioritas masalah, puskesmas membuat intervensi dengan melibatkan lintas sektor terkait. Semua intervensi yang sudah dilakukan berdasarkan pendataan KS, antara lain: TB Paru dengan melakukan penyuluhan individu, pembagian Leaflet, melibatkan kader memantau tersangka TB paru, bekerjasama dgn Ponpes utk mengirim suspek, pemeriksaan kontak serumah yang ada penderita TB, melibatkan mantan penderita TB yg sdh sembuh utk menjadi motivator penderita TB baru. Contoh lainnya progam merokok dengan melakukan penyuluhan kelompok lewat tokoh masyarakat/ PKK, penyuluhan pada remaja/anak sekolah SMP SMA, dan konseling di Puskesmas tentang bahaya merokok.

Demi kelangsungan pelaksanaan PIS-PK, maka dibuatlah rencana Monitoring, yaitu dengan membuat WAG KS yang anggotanya mulai dari berbagai tingkatan sehingga dapat melihat perkembangan pelaksanaan PIS PK di berbagai tingkatan yaitu mulai dari RT, RW, Kelurahan, Puskesmas sampai dengan Dinas Kesehatan. Di kabupaten Labuan Batu, analisa PIS-PK dilakukan oleh semua petugas yang melakukan entry data. Sehingga begitu diketahui nilai IKS selanjutnya diidentifikasi indikator mana yang cakupannya rendah untuk ditentukan skala prioritas intervensi. Saat intervensi melibatkan lurah sebagai kepala lingkungan. Lurah lebih berfungsi sebagai koordinator dan corong ke masyarakat.

Pada akhirnya Program Indonesia Sehat dengan Pendekatan Keluarga akan berkelanjutan dan menghasilkan data yang berkualitas jika hambatan-hambatan tersebut dapat diatasi dengan baik termasuk dengan melakukan pelatihan ulang para tenaga puskesmas dan memberikan kesempatan petugas puskesmas lainnya yang belum pernah mengikuti pelatihan untuk mendapatkan pelatihan PIS-PK. Selain itu dalam hal implementasi PIS-PK, penguatan 
lintas sektoral untuk intervensi-intervensi dalam menangani masalah-masalah kesehatan di keluarga perlu dilakukan dan dijalankan dengan baik. Tanpa adanya komitmen lintas sektoral yang kuat khususnya dengan kepala desa dan lurah sebagai pemangku kebijakan di level desa dan kelurahan maka PIS-PK hanya sekedar pendataan terhadap keluarga dan tidak akan menghasilkan perubahan-perubahan yang diharapkan pada ke-12 indikator yang telah ditetapkan sebelumnya. Komitmen lintas sektoral yang dimaksud diatas bisa diupayakan dalam kegiatan mini lokakarya antara puskesmas dengan aparat sipil pemerintahan desa/kelurahan.

\section{KESIMPULAN DAN SARAN}

\section{Kesimpulan}

Program Indonesia Sehat dengan Pendekatan Keluarga di Puskesmas Kabupaten Labuan Batu, dan Kota Semarang memang telah berjalan meskipun belum ada yang benar-benar mencapai target 100 persen kunjungan rumah tangga atau total cakupan di masing-masing Puskesmas. Hal tersebut terjadi karena masih ditemukannya hambatan dan kendala dalam pelaksanaan pendataan PIS-PK dan berimplikasi logis terhadap capaian pendataan di masing-masing tempat.

Dari sisi Puskesmas sebagai pelaksana program, dapat diidentifikasi beberapa permasalahan penting yang kemudian dapat mempengaruhi capaian target pendataan dan kualitas pendataan PISPK, antara lain : masih terbatasnya SDM di Puskesmas untuk melakukan pendataan dan kunjungan rumah tangga. Puskesmas memanfaatkan tenaga sukarela dan kader desa (yang tidak mendapatkan pelatihan PISPK) untuk melakukan pendataan.

Pemahaman pemegang progam PISPK di Puskesmas terhadap sumber atau alokasi pendanaan PIS-PK masih kurang, sehingga ada ketakutan untuk menggunakan data yang ada (seperti BOK) untuk memfasilitasi tenaga kesehatan melakukan pendataan ke rumah tangga.

Masih terdapat hambatan dalam melakukan pendataan karena ditemui keluarga yang tidak bersedia dikunjungi petugas dan mobilitas sebagian besar anggota rumah tangganya yang cukup tinggi membuat petugas Puskesmas sulit untuk melakukan wawancara terhadap semua anggota rumah tangga.

Masih terbatasnya sarana prasarana pendukung PIS-PK seperti perangkat komputer, akses jaringan internet, keterlambatan Puskesmas untuk mengajukan permohonan username dan password, serta sulitnya mengakses jaringan.

\section{Saran}

Agar PIS-PK ini berhasil diperlukan kesadaran kolektif dan menghilangkan egosentris progam dan sektoral. Puskesmas harus membuat hirarki petugas khusus PISPK. Petugas yang dilatih hanya dijadikan koordinatar dan sebagai pelatih, yang bertanggungjawab terhadap tenaga lapangan. Tenaga lapangan bisa berasal dari kader, tenaga honorer, mahasiswa magang, dan lainnya yang dilatih khusus mengenai PISPK. Agar kualitas pelatih bagus, tenaga yang dikirim untuk mengikuti pelatihan harus benar-benar tenaga terpilih yang sudah terbiasa mentransfer ilmu.

Untuk mengatasi kurangnya pendanaan PIS-PK bisa memanfaatkan dana CSR bila ada dan atau swadaya masyarakat. Bisa juga memanfaatkan kerjasama dengan kampus. Puskesmas menyediakan daerah magang lapangan mahasiswa untuk PIS-PK, dan pendanaan dari kampus tentunya.

Untuk mengatasi penolakan/ partisipasi masyarakat yang "menolak" perlu sosialisasi lebih intens dengan melibatkan unit internal Kemenkes maupun unit lintas sektor terkait.

\section{KONTRIBUTOR PENULIS}

Kontributor utama dalam penulisan artikel ini adalah N, NS, dan OSS, yang bertugas menulis artikel, menganalisa data kualitatif dan kuantitatif. Sedangkan penulis RSP, AA, EL dan JI sebagai kontributor anggota yang membantu dalam penyempurnaan pembahasan artikel. 


\section{UCAPAN TERIMAKASIH}

Penulis mengucapkan terima kasih kepada Puslitbang Upaya Kesehatan Masyarakat selaku penyandang dana dari kegiatan penelitian ini, kepada tim peneliti riset evaluasi program PIS-PK yang terlibat dari awal hingga akhir penelitian, kepada para Kepala Dinas dan Kepala Puskesmas yang telah memberikan waktunya hingga berbagai informasi yang sangat berguna untuk evaluasi program PIS-PK dapat dianalisa dengan baik.

\section{DAFTAR PUSTAKA}

Agustina, S. C., Trisnantoro, L. and Handono, D. (2019) 'Implementasi Program Indonesia Sehat dengan Pendekatan Keluarga (PIS PK) Menggunakan Tenaga Kontrak di Kabupaten Kulon Progo Tahun 2018', Jurnal Kebijakan Kesehatan Indonesia: JKKI, 8(3), pp. 104112.

Astuti, T. S. R. and Soewondo, P. (2019) 'Analisis Kesiapan Pembiayaan Hipertensi, Diabetes Melitus dan Gangguan Jiwa dalam Mendukung Program Indonesia Sehat dengan Pendekatan Keluarga (PIS PK) Tahun 20182020', Jurnal Ekonomi Kesehatan Indonesia, 3(1).

Badan Litbangkes RI (2013) Riset Kesehatan Dasar (RISKESDAS) 2013. Jakarta.

Badan Litbangkes RI (2017) Komplikasi Policy Brief 3, Hasil Litbangkes 2017 Edisi Ketiga. Jakarta.

Cushway, B. and Lodge, D. (1999) Organizational behaviour and design. Kogan Page Publishers.

Ernawati Roesli, D. (2018) 'Analisis Persiapan Implementasi Program Indonesia Sehat Dengan Pendekatan Keluarga (Indikator 8: Kesehatan Jiwa) di Kota Depok Tahun 2018', Jurnal Kebijakan Kesehatan Indonesia: JKKI, 7(2), pp. 64-73.

Eva Laelasari, dkk (2017) 'Evaluasi Kesiapan Pelaksanaan Program Indonesia Sehat dengan
Pendekatan Keluarga', Indonesian Journal of Health Ecology. National Institute of Health Research and Development, Indonesian Ministry ..., 16(2), pp. 57-72.

Fauzan, A., Chotimah, I. and Hidana, R. (2019) 'implementasi program indonesia sehat dengan pendekatan keluarga (pis-pk) di puskesmas mulyaharja kota bogor tahun 2018', promotor, 2(3), pp. 172-181.

Kementerian Kesehatan RI (2014) 'peraturan menteri kesehatan ri no 75 tahun 2014 tentang pusat kesehatan masyarakat'. Kementerian Kesehatan Republik Indonesia.

Kementerian Kesehatan RI (2015) Keputusan Menteri Kesehatan Republik Indonesia No 52 tahun 2015, tentang Rencana Strategis di Bidang Kesehatan. Jakarta.

Kementerian Kesehatan RI (2016) 'peraturan menteri kesehatan republik indonesia nomor 39 tahun 2018 tentang organisasi dan tata kerja unit pelaksana teknis bidang pelatihan kesehatan di lingkungan badan pengembangandan pemberdayaan sumber daya manusia kesehatan kementerian kesehatan'. Kemenkes RI.

Laelasari, E. (2016) Laporan Penelitian Evaluasi Keluarga Sehat tahun 2016. Jakarta.

Laelasari, E. et al. (2019) 'model intervensi hipertensi di puskesmas purwoyoso, semarang', Jurnal Ekologi Kesehatan, 18(1), pp. 15-26.

Roeslie, E. (2018) 'Analisis Persiapan Implementasi Program Indonesia Sehat Dengan Pendekatan Keluarga (Indikator 8: Kesehatan Jiwa) di Kota Depok Tahun 2018', Jurnal Kebijakan Kesehatan Indonesia: JKKI, 7(2), pp. 64-73.

Sulistiyowati, N. (2017) Laporan Penelitian: Riset Evaluasi Progam Indonesia Sehat Dengan Pendekatan Keluarga (PIS PK): Dinamika PIS PK di Beberapa Kabupaten Kota di Indonesia tahun 2017. Jakarta.

Virdasari, E., Arso, S. P. and Fatmasari, E. Y. (2018) 'analisis kegiatan pendataan keluarga program indonesia sehat dengan pendekatan keluarga di puskesmas kota semarang (Studi Kasus pada Puskesmas Mijen)', Jurnal Kesehatan Masyarakat (e-Journal), 6(5), pp. 52-64. 